\title{
ANALISIS PENERAPAN SANKSI PIDANA TERHADAP TINDAK PIDANA PENGGELAPAN DALAM JABATAN (Studi Putusan Nomor 71/Pid.B/2019/Pn.Mgl)
}

\author{
Aprinisa ${ }^{1}$ \\ Muhammad Faried Nurqomahruddin ${ }^{2}$ \\ Fakultas Hukum Universitas Bandar Lampung \\ Jl. ZA Pagar Alam No 26 Labuhan Ratu Bandar Lampung \\ Email: aprinisa@ubl.ac.id
}

\begin{abstract}
ABSTRAK
Penggelapan adalah suatu tindak pidana yang dilakukan dengan sengaja dan melawan hukum yang mengaku sebagai pemilik dari sesuatu sendiri yang seluruhnya atau sebagian dimiliki oleh orang lain dalam kekuasaannya, yang diperoleh bukan karena tindak pidana. Permasalahan dalam penelitian ini adalah bagaimana penerapan hukum pidana terhadap penggelapan dalam jabatan dan bagaimana pertimbangan hakim dalam menjatuhkan hukuman. Metode penelitian yang digunakan dalam penelitian ini adalah pendekatan yuridis normatif dan empiris. Data yang digunakan adalah data primer dan data sekunder. Setelah data terkumpul kemudian dianalisis secara kualitatif untuk mendapatkan kesimpulan. Berdasarkan hasil penelitian ditemukan bahwa: penerapan hukum pidana materiil oleh Majelis Hakim terhadap pelaku penipuan penggelapan dalam jabatan yang menyatakan terdakwa sah dan terbukti bersalah melakukan penggelapan dalam jabatan sebagaimana dimaksud dalam pasal 374 KUHP Jo Pasal 55 ayat (1) 1 adalah benar. Hal itu sesuai dengan fakta persidangan, alat bukti dan keterangan saksi. Dan terdakwa dianggap sehat jasmani dan rohani sehingga mampu mempertanggungjawabkan perbuatannya. Penerapan sanksi juga sesuai dengan aturan hukum kewenangan masing-masing lembaga dan peraturan yang mengaturnya. Pertimbangan hukum oleh Majelis Hakim dalam nilai yang benar. Karena berdasarkan fakta-fakta yang terungkap di persidangan, serta keterangan saksi dan keterangan terdakwa, perbuatan terdakwa telah memenuhi unsur-unsur tindak pidana penggelapan di kantor dengan pemberat sebagai delik final, sebagaimana diatur dalam Pasal 374 UU No. KUHP Jo Pasal 55 ayat (1) KUHP dan terdakwa memenuhi syarat sebagai subjek hukum.
\end{abstract}

Kata kunci: sanksi pidana, penggelapan, jabatan

\section{PENDAHULUAN}

Dalam kehidupan sehari-hari manusia sering dihadapkan kepada suatu kebutuhan yang mendesak kebutuhan pemuas diri bahkan kadang-kadang karena keinginan atau desakan untuk mempertahan status diri. Secara umum kebutuhan manusia itu akan dapat dipenuhi, walaupun tidak seluruhnya, dalam keadaan yang tidak memerlukan desakan dari dalam atau orang lain. Terhadap kebutuhan yang mendesak pemenuhannya dan harus dipenuhi dengan segera biasanya sering dilaksanakan tanpa pemikiran matang yang dapat merugikan lingkungan atau manusia lain. Hal seperti itu kana menimbulkan suatu akibat negatif yang tidak seimbang dengan suasana dan kehidupan yang bernilai baik.

Hukum seringkali dipahami oleh masyarakat sebagai suatu perangkat aturan yang dibuat oleh negara yang mengikat warga negaranya dengan mekanisme keberadaan sanksi sebagai pemaksa untuk menegakkan hukumnya dan demi keseragaman dan kesejahteraan dalam masyarakat. Negara mempunyai hak untuk memaksa diberlakukannya sanksi terhadap perbuatan yang melanggar hukum dimana pelakunya dinyatakan salah oleh putusan pengadilan yang mempunyai kekuatan hukum tetap berdasarkan bukti bukti yang telah di kumpulkan dan dihadirkan dalam persidangan. 
Menurut Teguh Prasetyo (2011:7) Hukum mempunyai 3 (tiga) peranan utama dalam masyarakat, yaitu pertama, sebagai sarana pengendalian sosial, kedua sebagai sarana untuk memperlancar proses interaksi sosial dalam masyarakat dan ketiga sebagai sarana untuk menciptakan keadaan tertentu.

Suatu perbuatan yang dibentuk menjadi kejahatan atau pelanggaran dirumuskan dalam Undang-Undang Republik Indonesia (selanjutnya disingkat UURI) sebagai perbuatan yang membahayakan dan menganggu suatu kepentingan hukum. Dengan menetapkan larangan untuk melakukan suatu perbuatan dengan disertai ancaman atau sanksi pidana bagi barang siapa yang melanggarnya atau bertindak melawan hukum, berarti Undang-Undang telah memberikan perlindungan hukum atas kepentingan-kepentingan hukum yang diatur tersebut.

Berjalannya hukum yang dinamis menyebabkan perkembangan tindak kriminal seiring berkembangnya zaman semakin marak dan semakin beragam. Hal tersebut tidak lepas dari perkembangan zaman yang semakin canggih sehingga modus tindak pidana tersebut pun semakin canggih. Perkembangan tersebut sangat mempengaruhi berbagai pihak/oknum untuk melakukan atau menghalalkan segala cara yang dapat berimbas pada kerugian dari segi kekayaan yang akan diderita oleh seseorang yang menjadi korban dalam kejahatan tersebut.

Perlu disadari bahwa kejahatan saat ini dapat dilakukan oleh siapapun dan terhadap siapapun, seiring dengan perkembangan zaman yang semakin maju maka semakin meningkat pula kejahatan yang terjadi di lingkungan masyarakat misalnya seperti kejahatan pencurian, pembunuhan, perampokan, penipuan, penggelapan, perkosaan, penculikan dan sebagainya.

Kejahatan dan pelanggaran merupakan suatu fenomena kompleks yang pemahamannya juga berbeda sehingga pendapat terhadap kejahatan dan pelanggaran sering kali berbeda. Suatu perbuatan yang dibentuk menjadi kejahatan atau pelanggaran dirumuskan dalam Undang-Undang lataran dianggap sebagai perbuatan yang dapat mengancam kepentingan hukum. Penaggulangan dan pengambilan keputusan terhadap kejahatan dengan mengunakan sanksi pidana merupakan cara paling tua, setua peradaban manusia itu sendiri. Kejahatan yang terjadi dalam masyarakat tentunya mendapat reaksi dari masyarakat tempat kejahatan itu terjadi. Beberapa studi terhadap reaksi masyarakat terhadap kejahatan ini ternyata menunjukan hubungan yang signifikan antara reaksi masyarakat dengan terjadinya kejahatan.

Kejahatan dalam kehidupan manusia merupakan merupakan masalah dan gejala sosial yang akan selalu dihadapi oleh setiap manusia, masyarakat dan bahkan Negara. Masalah kejahatan bukanlah masalah yang baru meskipun tempat dan waktunya berbeda tetapi modus operandinya dinilai sama. Namun ringan dan beratnya setiap ancaman hukuman tidak menjadi penghalang seseorang untuk tidak melakukan kejahatan atau pun pelanggaran. Hal ini menjadi masalah sebab tidak berarti sebuah aturan hukum jika kejahatan yang dilakukan masyarakat tidak dapat diikuti oleh aturan hukum itu sendiri atau tdak dilindungi oleh negara dengan adanya peraturan yang kongkrit, seperti kejahatan dengan cara penggelapan yang merupakan salah satu dari jenis kejahatan terhadap harta benda manusia.

Berbagai tindak pidana yang terjadi dimasyarakat, salah satu yang sering terjadi ialah tindak pidana pengelapan. Tindak pidana penggelapan yang merupakan kejahatan sering sekali terjadi diberbagai bidang dan bahkan pelakunya diberbagai lapisan masyarakat. Baik lapisan kelas bawah, kelas tengah maupun lapisan kelas atas yang melakukan tindak pidana ini. Melihat banyaknya kasus penggelapan yang terjadi di Indonesia 
tentunya ini sangat memprihatinkan. Tindak pidana penggelapan yang merupakan kejahatan yang berawal dari adanya suatu kepercayaan kepada orang lain, dan kepercayaan tersebut hilang karena lemahnya suatu kejujuran. Bahkan dewasa ini banyak terjadi kasus penggelapan dengan berbagai modus yang menunjukan semakin tinggi dan beragamnya tingkat kejahatan yang terjadi. Di sisi lain tindak kejahatan yang marak terjadi yakni tindak pidana penggelapan sebagaimana yang diatur dalam Pasal 372 sampai dengan Pasal 377 KUHP. Tindak pidana sebagaimana tersebut sebagai "penyalah-gunaan kepercayaan". Sebab, inti dari tindak pidana yang diatur dalam pasal tersebut adalah "penyalahgunaan hak" atau "penyalahgunaan kepercayaan" (Abdul Halim, 1996:52).

Penyalahgunaan kepercayaan yang mendominasi sebagai unsur tindak pidana pengelapan ini. Kejahatan penggelapan diatur dalam Kitab Undang-Undang Hukum Pidana (selanjutnya disingkat dengan KUHP) (Pasal 372 (penggelapan biasa), Pasal 373 (penggelapan ringan), Pasal 374 dan Pasal 375 (penggelapan dengan pemberatan) dan Pasal 376 (penggelapan dalam keluarga).

Pasal 374 pada dasarnya hanyalah pemberatan dari Pasal 372 KUHP, yaitu apabila penggelapan tersebut dilakukan dalam hubungan jabatan sehingga kalau Pasal 374 KUHP dapat dibuktikan maka Pasal 372 KUHP dengan sendirinya dapat dibuktikan juga Disisi lain, tindak pidana penggelapan memiliki masalah yang berhubungan erat dengan sikap, moral, mental, kejujuran dan kepercayaan manusia sebagai individu dalam sebuah masyarakat.

Berdasarkan uraian tersebut dapat diketahui bahwa tindak pidana penggelapan merupakan suatu perbuatan pidana yang dilakukan dengan sengaja dan melawan hukum mengaku sebagai pemilik sendiri barang sesuatu seluruhnya atau sebagian adalah milik orang lain yang ada dalam kekuasaannya, yang diperoleh bukan karena kejahatan. Adapun kasus yang terkait dengan tindak pidana penggelapan yang akan diangkat dan dibahas oleh penulis dalam penelitian ini adalah tindak pidana penggelapan yang terjadi di wilayah hukum kabupaten Tulang Bawang dengan menggunakan jabatan yang dilakukan oleh terdakwa Solihin bin Suwito yang menjabat sebagai kepala Depo Unit II PT. ABUN yang di duga menggelapkan barang-barang PT. ABUN di dalam gudang juga menjadi tanggung jawab terdakwa. Bahwa terdakwa memerintah saksi untuk membuat faktur fiktif dengan tujuan agar barang yang terdapat digudang sesuai dengan jumlah barang yang ada didalam sistem. Akibat perbuatan terdawa pihak PT.ABUN mengalami kerugian materiil sebesar Rp.84.342.600,- (delapan puluh empat juta tiga ratus empat puluh dua ribu dua ratus rupiah), penuntut umum mendakwa terdakwa terbukti secara sah dan meyakinkan bersalah melakukan tindak pidana "yang melakukan penggelapan dalam jabatan" sebagaimana diatur dan diancam pidana dalam Pasal 374 KUHP jo Pasal 55 Ayat (1) KUHP dengan pidana penjara selama 2 (dua) tahun.

Berdasarkan latar belakang yang telah dijabarkan diatas, maka penulis tertarik untuk memilih judul Analisis Penerapan Sanksi Pidana Terhadap Tindak Pidana Penggelapan Dalam Jabatan (Studi Putusan Nomor 71/Pid.B/2019/Pn.Mgl). permasalahan dalam penelitian ini adalah:

a. Bagaimana penerapan hukum pidana terhadap tindak pidana penggelapan dalam jabatan oleh Kepala Depo Unit II Kabupaten Tulang Bawang terhadap barang-barang PT. Anugrah Bina Usaha Nusantara (ABUN)?

b. Bagaimana pertimbangan hakim dalam menjatuhkan sanksi tindak pidana penggelapan dalam jabatan oleh Kepala Depo Unit II Kabupaten Tulang Bawang terhadap barangbarang PT. Anugrah Bina Usaha Nusantara (ABUN) pada putusan 
perkara

Nomor

71/Pid.B/2019/Pn.Mgl)?

Metode penelitian yang digunakan dalam penulisan skripsi ini ialah pendekatan yuridis normatif dan empiris. Data yang digunakan yaitu data sekunder dan data primer. Data sekunder ialah data yang didapat dari studi kepustakaan, serta pendekatan ini didukung oleh tiga bahan yaitu bahan hukum primer, sekunder dan tersier. Data primer ialah data yang di dapat dari lapangan secara langsung pada objekpenelitian. Data yang selanjutnya dianalisis dan dibahas secara yuridis kualitatif, yakni dengan memberikan pengertian terhadap data yang dimaksud menurut kegiatan yang diperoleh di lapangan dan disusun serta diuraikan dalam bentuk kalimat untuk mendapatkan kesimpulan.

\section{PEMBAHASAN}

\section{A. Penerapan Hukum Pidana Terhadap Tindak Pidana Penggelapan Dalam Jabatan Oleh Kepala Depo Unit II Kabupaten Tulang Bawang Terhadap Barang-Barang PT. Anugrah Bina Usaha Nusantara (ABUN).}

Menurut hasil wawancara dengan Bapak Sandi Galih Putra selaku Penyidik Kepolisian Polres Menggala berdasarkan Berita Acara Pemeriksaan kasus Terdakwa SOLIHIN Bin SUWITO yang menjabat selaku Kepala Depo Unit II PT. Anugerah Bina Usaha Nusantara (PT.ABUN) yang bergerak pada bidang usaha distribusi food dan non food yang salah satu Deponya berada di Unit 2 Kabupaten Tulang Bawang, bersama-sama dengan saksi Yohanes Adi Saputra Anak Dari Suko Adi selaku Kepala Gudang. Pada kurun waktu pada bulan Maret Saksi Dian yang menjabat selaku Administrasi diperintahkan oleh Terdakwa SOLIHIN Bin SUWITO dan saksi Yohanes untuk mencetak 9 (sembilan) faktur penjualan.
Terdakwa terlebih dahulu membuatkan surat pesanan fiktif dengan maksud untuk dinput kedalam System ACTS yang akan dilihat dalam pelaporan seolah-olah barang sudah terjual namun sebenarnya barang diambil sendiri oleh Terdakwa dan saksi Yonahes kemudian oleh saksi Dian hal tersebut juga diberitahukan kepada saksi Yohanes selaku kepala gudang dan saksi Yohanes menekankan untuk segera mencetak dan selain itu saksi Dian juga diminta untuk mencetak Faktur batal sebanyak 2 (dua) faktur.

Kemudian pada tanggal 22 Mei 2018 Kantor Pusat PT.ABUN mencurigai ada kejanggalan dalam setiap Laporan bulanan yang dibuat oleh Terdakwa kemudian dilakukan audit dan Tim Audit mendapati adanya 9 (sembilan) faktur penjualan fiktif dan 2 (dua) faktur batal fiktif hal ini setelah dilakukan factual ke toko yang dimaksud dalam faktur dan setelah dimintai keterangan pihak toko tidak pernah menerima barang yang dimaksud dalam faktur-faktur tersebut. Selain itu Tim Audit juga menemukan adanya stock barang yang tersedia didalam gudang tidak sesuai dengan stock barang yang terdapat didalam sistem serta adanya Faktur-faktur yang hilang.

Akibat Perbuatan Terdakwa bersamasama dengan Saksi Yohanes mengakibatkan Pihak PT.ABUN mengalami kerugian materiil sebesar Rp.84.342.600,- (delapan puluh empat juta tiga ratus empat puluh dua ribu dua ratus rupiah). Lalu kemudian penyampaian Bapak Sandi Galih Putra Perbuatan Terdakwa tersebut diatur dan dapat diancam pidana sebagaimana dimaksud dalam Pasal 374 KUHP Jo Pasal 55 ayat (1) KUHP.

Menurut hasil wawancara dengan Ibu Desmi Yulian selaku Kepala Sub Bagian Pembinaan Kejaksaan Negeri Tulang Bawang menerangkan bahwa sebelum Jaksa Penuntut umum membuat surat dakwaan dan melimpahkan berkas perkara kepada Pengadilan Negeri, terlebih dahulu 
harus ada penyerahan Berita Acara Pemeriksaan (BAP) dari pihak penyidik, jika Berita Acara Pemeriksaan dari pihak penyidik telah lengkap menurut Jaksa Penuntut Umum, barulah selaras dengan Berita Acara Pemeriksaan tersebut.

Menurut hasil wawancara dengan Ibu Desmi Yulian selaku Kepala Sub Bagian Pembinaan Kejaksaan Negeri Tulang Bawang menerangkan bahwa surat dakwaan merupakan dasar atau landasan pemeriksaan perkara dalam sidang pengadilan sedangkan surat tuntutan adalah surat yang berisi tuntutan Penuntut Umum terhadap suatu tindak pidana. Pada hakikatnya seorang Jaksa Penuntut Umum harus membuat surat dakwaan dan surat tuntutan yang membuat pelaku/terdakwa suatu tindak pidana tidak dapat lolos dari jerat hukum. Hakim dalam memeriksa suatu perkara tidak boleh menyimpang dari apa yang dirumuskan di dalam surat dakwaan. Seorang terdakwa hanya dapat dijatuhi hukuman karena telah dibuktikan dalam persidangan bahwa ia telah melakukan tindak pidana seperti apa disebutkan atau yang dinyatakan jaksa dalam surat dakwaan.

Menurut hasil wawancara dengan Ibu Desmi Yulian selaku Kepala Sub Bagian Pembinaan Kejaksaan Negeri Tulang Bawang menerangkan bahwa Terdakwa diajukan ke persidangan oleh Penuntut Umum didakwa berdasarkan surat dakwaan sebagai berikut : "Mereka yang melakukan Dengan sengaja dan melawan hukum mengaku sebagai milik sendiri barang sesuatu yang seluruhnya atau sebagian adalah kepunyaan orang lain tetapi yang ada dalam kekuasaannya bukan karena kejahatan dilakukan oleh orang yangkarena jabatannya atau mendapatkan upah", Perbuatan Terdakwa tersebut diatur dan diancam pidana sebagaimana dimaksud dalam Pasal 374 KUHP Jo Pasal 55 ayat (1) KUHP;

Menurut hasil wawancara dengan Ibu Desmi Yulian selaku Kepala Sub Bagian Pembinaan Kejaksaan Negeri Tulang Bawang menerangkan bahwa berdasarkan alat bukti dan barang bukti yang diajukan diperoleh fakta-fakta hukum sebagai berikut:

1. Bahwa peristiwa penggelapan tersebut terjadi Pada Kurun waktu bulan Januari sampai dengan Mei tahun 2018, bertempat di Kantor Depo PT. Anugerah Bina Usaha Nusantara (PT.ABUN) yang beralamat di Unit Kabupaten Tulang Bawang.

2. Bahwa berawal dari Terdakwa dan saksi Yohanes memerintahkan Saksi Dian yang menjabat selaku Administrasi untuk mencetak 9 (sembilan) faktur penjualan yang isi fiktif yaitu :

a. U/FJ/ATB/03/18/00899, tertanggal 24 Maret 2018 dengan merek barang DC-KRIMER KENTAL MANIS 500/505 sebanyak 3 dus seharaga Rp. 1.434.500,- kepada toko FIESTA Pasar Unit 2 Tulang Bawang.

b. U/FJ/ATB/03/18/00993, tertanggal 30 Maret 2018 dengan merek barang KOMIX JAHE GFORMULA 30S 50X30 sebanyak 10 Dus dengan harga Rp. 13.822.500,- kepada Toko NURCHOLIS Pasar SPU A Simpang Pematang.

c. U/FJ/ATB/03/18/00994, tertanggal 30 Maret 2018 dengan merek barang KOMIX JAHE GFORMULA 30S 50X30 sebanyak 10 Dus dengan harga Rp. 13

d. U/FJ/ATB/03/18/00995 tertanggal 30 Maret 2018 dengan merek barang KOMIX JAHE GFORMULA 30S 50X30 sebanyak 10 Dus dengan harga Rp. 13.822.500,- Kepada toko HENDRA Pasar Unit 2 Tulang Bawang.

e. U/FJ/ATB/03/18/01003, tertanggal 30 Maret 2018 dengan merek barang KOMIX JAHE GFORMULA 30S 50X30 sebanyak 10 Dus dengan harga Rp. 
13.822.500,- Kepada Toko NARDI Pasar SPUA Simpang Pematang.

f. U/FJ/ATB/03/18/01004, tertanggal 30 Maret 2018 dengan merek barang KOMIX JAHE GFORMULA 30S 50X30 sebanyak 10 Dus dengan harga Rp. 13.822.500,- Toko AHUN Jalan Etanol No 11 Pasar unit 2 Tulang Bawang.

g. U/FJ/ATB/03/18/01005, tertanggal 30 Maret 2018 dengan merek barang KOMIX JAHE GFORMULA 30S 50X30 sebanyak 5 Dus dengan harga Rp. 6.911.250,Kepada Toko Mami Pasar SPUA Simpang Pematang Mesuji.

h. U/FJ/ATB/03/18/01006, tertanggal 30 Maret 2018 dengan merek barang KOMIX JAHE GFORMULA 30S 50X30 sebanyak 5 Dus dengan harga Rp. 6.911.250,Kepada Toko Bambang Pasar Unit 2 Tulang Bawang.

i. U/FJ/ATB/03/18/01046, tertanggal 09 April 2018 dengan merek barang EXTRA JOSS ACTIVE @ 12X5 sebanyak 3 Dus seharga Rp.1.746.000,- Kepada toko MISTIYAH Pasar Unit 2. Tulang Bawang

Menurut hasil wawancara dengan Ibu Desmi Yulian selaku Kepala Sub Bagian Pembinaan Kejaksaan Negeri Tulang Bawang menerangkan bahwa adapun dalam Berita Acara Pemeriksaan tersebut, terdakwa telah terbukti melakukan Tindak Pidana Penggelapan sebagaimana dimaksud dalam Pasal 374 KUHP Jo Pasal 55 ayat (1) KUHP sebagaimana yang kami dakwakan dalam dakwaan tunggal sebagaimana diatur pada Pasal 374 KUHP Jo Pasal 55 ayat (1) KUHP dan Berita Acara tersebut telah lengkap yang disertai dengan alat-alat bukti dan keterangan para saksi yang dianggap telah sah menurut hukum, serta Berita Acara Pemeriksaan telah berjalan sesuai dengan dakwaan yang dibuat oleh Jaksa Penuntut Umum.
Menurut hasil wawancara dengan Bapak Donny selaku Hakim Pengadilan Negeri Menggala menerangkan bahwa Majelis Hakim dengan memperhatikan fakta-fakta hukum tersebut diatas memilih langsung dakwaan Tunggal sebagaimana diatur dalam Pasal 374 KUHP Jo Pasal 55 ayat (1) KUHP, yang unsur-unsurnya adalah sebagai berikut :

1. Barang siapa ;

2. Dengan sengaja dan melawan hukum

3. Melakukan penggelapan yang penguasaannya terhadap barang disebabkan karena ada hubungan kerja atau karena pencarian atau karena mendapatkan upah untuk itu

4. Mereka yang melakukan, yang menyuruh melakukan dan yang turut serta melakukan;

Menurut hasil wawancara dengan Bapak Donny selaku Hakim Pengadilan Negeri Menggala menerangkan bahwa putusan yang di jatuhkan kepada terdakwa berdasarkan kualitas kesalahannya dengan melihat latar belakang dari pada tindak pidana tersebut dimana sanksi pidana yang di jatuhkan telah sesuai dengan Pasal 374 KUHP Jo Pasal 55 ayat (1) KUHP yang berisi "Barang siapa melakukan Dengan sengaja dan melawan hukum mengaku sebagai milik sendiri barang sesuatu yang seluruhnya atau sebagian adalah kepunyaan orang lain tetapi yang ada dalam kekuasaannya bukan karena kejahatan dilakukan oleh orang yangkarena jabatannya atau mendapatkan upah". Perbuatan yang dianggap sebagai perbuatan pidana.

Menurut hasil wawancara dengan Bapak Donny selaku Hakim Pengadilan Negeri Menggala menerangkan bahwa sebelum majelis hakim menjatuhakan putusannya terlebih dahulu akan memepertimbangkan hal-hal yang memberatkan dan meringankan terdakwa agar putusan untuk terdakwa tidak mementingkan sebelah pihak.

Bahwa untuk menjatuhkan pidana terhadap Terdakwa maka perlu dipertimbangkan terlebih dahulu keadaan 
yang memberatkan dan yang meringankan Terdakwa :

Keadaan yang memberatkan:

- Akibat perbuatan Terdakwa Pihak PT.ABUN mengalami kerugian materiil sebesar Rp.84.342.600,-- (delapan puluh empat juta tiga ratus empat puluh dua ribu dua ratus rupiah);

Keadaan yang meringankan:

- Terdakwa belum pernah dihukum;

- Terdakwa mengakui dan menyesali perbuatannya;

-Terdakwa bersikap sopan dipersidangan;

Menurut hasil wawancara dengan Bapak Donny selaku Hakim Pengadilan Negeri Menggala menerangkan bahwa berdasarkan pertimbangan hukum, Majelis Hakim berpendapat bahwa terdakwa telah terbukti secara sah dan meyakinkan bersalah melakukan tindak pidana "yang melakukan Penggelapan dalam jabatan", sebagaimana diatur dan diancam pidana dalam Pasal 374 KUHP Jo Pasal 55 ayat (1) KUHP dan Undang-undang Nomor 8 Tahun 1981 tentang Hukum Acara Pidana dan oleh karenanya terdakwa dinyatakan bersalah dan dijatuhi pidana yang setimpal dengan perbuatannya.

Berdasarkan Pasal 374 KUHP Jo Pasal 55 ayat (1) KUHP dan Undang-undang Nomor 8 Tahun 1981 tentang Hukum Acara Pidana serta peraturan perundangundangan lain yang bersangkutan;

1. Menyatakan Terdakwa Solihin Bin Suwito terbukti secara sah dan meyakinkan bersalah melakukan tindak pidana "yang melakukan Penggelapan dalam jabatan".

2. Menjatuhkan pidana kepada Terdakwa Solihin Bin Suwito oleh karena itu dengan pidana penjara selama 2 (dua) Tahun dengan ketentuan selama Terdakwa dalam masa tahanan dikurangkan seluruhnya dari pidana yang dijatuhkan kepadanya dengan perintah Terdakwa tetap dalam tahanan.

3. Memerintahkan Terdakwa tetap berada dalam tahanan;
Berdasarkan uraian diatas dapat dianalisis bahwa putusan kasus Nomor 71/Pid.B/2019/PN.Mgl menyatakan bahwa terdakwa SOLIHIN Bin SUWITO terbukti bersalah melakukan tindak pidana penggelapan dalam jabatan. Sebagaimana yang diatur dalam pasal 374 KUHP Jo Pasal 55 ayat (1) KUHP yang berbunyi "barangsiapa Dengan sengaja dan melawan hukum mengaku sebagai milik sendiri barang sesuatu yang seluruhnya atau sebagian adalah kepunyaan orang lain tetapi yang ada dalam kekuasaannya bukan karena kejahatan dilakukan oleh orang yang karena jabatannya atau mendapatkan upah" dan dalam kasus ini terdakwa didakwakan pasal 374 KUHP mengenai penggelapan dalam jabatan dan pasal 55 ayat (1) KUHP mengenai turut serta karena telah sesuai dengan posisi kasus diatas, terdakwa terbukti bersalah karena dengan sengaja dan dengan sadar menggelapkan atau mengeluarkan barang tanpa melalui prosedur yang resmi dari kantor Depo PT. Anugerah Bina Usaha Nusantara (PT.ABUN) yang bergerak pada bidang usaha distribusi food dan non food yang atas jabatan yang dipegangnya dan turut serta melakukan penggelapan dalam jabatan dalam menjalankan kejahatannya. Sehingga terdakwa terbukti telah memenuhi unsur yang terdapat pada pasal 374 KUHP dan pasal 55 ayat (1) KUHP

\section{B. Pertimbangan Hakim Dalam Menjatuhkan Sanksi Tindak Pidana Penggelapan Dalam Jabatan Oleh Kepala Depo Unit II Kabupaten Tulang Bawang Terhadap Barang- Barang PT. Anugrah Bina Usaha Nusantara (ABUN) pada putusan perkara Nomor 71/Pid.B/2019/Pn.Mgl)}

Menurut hasil wawancara dengan Bapak Donny selaku Hakim Pengadilan Negeri Menggala menerangkan bahwa suatu proses peradilan diakhiri dengan penjatuhan putusan akhir (vonis), aspek pertimbangan-pertimbangan yuridis 
terhadap tindak pidana yang didakwakan merupakan konteks yang paling dalam putusan hakim. Hakikatnya pada pertimbangan yuridis merupakan pembuktian perbuatan terdakwa terhadap unsur-unsur tindak pidana.

Menurut hasil wawancara dengan Bapak Donny selaku Hakim Pengadilan Negeri Menggala menerangkan bahwa Setiap pemeriksaan melalui proses acara pidana, keputusan hakim haruslah selalu didasarkan atas surat perlimpahan perkara yang memuat seluruh dakwaan atas kesalah terdakwa. Selain itu keputusan hakim juga harus tidak boleh terlepas dari hasil pembuktian selama pemeriksaan dan hasil sidang pengadilan. Proses untuk menentukan bersalah tidaknya perbuatan yang dilakukan oleh seseorang merupakan kekuasaan kehakiman, artinya hanya jajarannyalah yang diberi wewenang untuk memeriksa dan mengadili setiap perkara yang datang untuk diadili.Keputusan hakim harus mencerminkan keadilan. Keadilan menurut hakim sering diartikan dengan sebuah kemenangan dan kekalahan oleh pencari keadilan. Penting kiranya untuk memberikan pemahaman bahwa sebuah keadilan itu bersifat abstrak, tergantung dari sisi mana kita memandangnya. Oleh karena itu dalam rangka memaksimalkan tujuan hukum maka kita tidak hanya memenuhi rasa kepastian hukum tetapi juga memenuhi rasa keadilan.

Menurut hasil wawancara dengan Bapak Donny selaku Hakim Pengadilan Negeri Menggala menerangkan bahwa sebelum menjatuhkan putusannya Hakim mempertimbangkan tentang alat-alat bukti yang digunakan dalam persidangan tersebut sebagaimana tercantum dalam ketentuan Pasal 183 KUHAP yang merumuskan sebagai berikut: "Hakim tidak boleh menjatuhkan kepada seseorang kecuali apabila dengan sekurangkurangnya dua alat bukti yang sah ia memperoleh keyakinan bahwa suatu tindak pidana benar-benar terjadi dan bahwa terdakwalah yang bersalah melakukannya"
Menurut hasil wawancara dengan Bapak Donny selaku Hakim Pengadilan Negeri Menggala menerangkan bahwa dalam kasus putusan nomor 71/Pid.B/2019/PN.Mgl terdakwa Solihin Bin Suwito dinyatakan dalam persidangan oleh majelis hakim terbukti secara sah dan meyakinkan bersalah melakukan penggelapan dalam jabatan. Dan hakim menjatuhkan hukuman terhadap terdakwa Muhammad Syarif dengan 7 (tujuh) tahun penjara.

Penerapan pasal 374 KUHP Jo Pasal 55 ayat (1) KUHP dalam dakwaan tersebut dirasa sudah tepat dikarenakan terdakwa turut serta dalam kejahatan yang dilakukan oleh Solihin Bin Suwito dengan menggunakan jabatan yang ia miliki untuk mengeluarkan barang dari PT. Anugerah Bina Usaha Nusantara (PT.ABUN) tanpa melalui prosedur yang resmi.

Hasil wawancara dengan Bapak Donny selaku Hakim Pengadilan Negeri Menggala menerangkan bahwa dalam putusan majelis hakim dimana terdakwa dinyatakan secara sah dan meyakinkan bersalah melakukan tindak pidana penggelapan dalam jabatan. Adapun pertimbangan hakim terhadap tindak pidana penggelapan dalam jabatan yang dilakukan oleh terdakwa adalah sebagai berikut :

Bahwa Terdakwa telah didakwa oleh Penuntut Umum dengan dakwaan yang berbentuk Tunggal, sehingga Majelis Hakim dengan memperhatikan fakta-fakta hukum tersebut diatas memilih langsung dakwaan Tunggal sebagaimana diatur dalam Pasal 374 KUHP Jo Pasal 55 ayat (1) KUHP, yang unsur-unsurnya adalah sebagai berikut :

1. Barang siapa

Yang dimaksud unsur barang siapa adalah orang sebagai subjek hukum yang kepadanya dapat dipertanggungjawabkan atas perbuatannya. Maka berdasarkan penjabaran diatas barang siapa dalam perkara ini adalah terdakwa solihin bin suwito sebagai subjek hukum yang berdasarkan berkas perkara dan surat 
dakwaan yang didakwakan dalam dakwaan tunggal pasal 374 KUHP jo pasal 55 ayat (1) KUHP.

Secara objektif, terdakwa di persidangan telah menunjukkan kecakapan dan kemampuan secara fisik maupun phsychis yang sehat sehingga tidak terdapat halangan untuk mempertanggungjawabkan perbuatannya secara hukum. Hal ini telah pula dibuktikan pada waktu majelis hakim yang mengadili perkara terdakwa di persidangan yang terbuka untuk umum pada permulaan persidangan menanyakan identitas terdakwa yang didasarkan pada berkas perkara dan surat dakwaan kami yang dijawab oleh terdakwa dengan membenarkan identitas tersebut.

Mengenai identitas terdakwa tersebut telah pula dibenarkan oleh saksi-saksi yang memberikan keterangan di bawah sumpah sehingga menjadi fakta hukum bahwa benar terdakwa solihin bin suwito yang diajukan di persidangan sesuai dengan identitas terdakwa dalam surat dakwaan, sehingga dengan demikian dalam mengajukan terdakwa sebagai subjek hukum yang akan diminta pertanggungjawaban pidana atas perbuatan yang ia lakukan tidak terjadi kesalahan terhadap orangnya (error in persona), sehingga tidak pula terdapat alasan untuk meniadakan / menghapuskan / membenarkan perbuatan pidana yang dilakukannya. Karena itu terhadap diri Terdakwa tersebut di atas dapat di pertanggungjawabkan secara hukum pidana dan dengan demikian unsur "Barang siapa" tersebut telah terpenuhi menurut hukum.

2. Dengan sengaja dan melawan hukum

a. Sengaja sebagai maksud (tujuan) adalah terjadinya suatu tindakan Pidana atau akibat tertentu dari perbuatan itu merupakan perwujudan dari maksud dan tujuan yang dikehendaki oleh pelaku.

b. Sengaja sebagai kemungkinan adalah sengaja yang dilakukan oleh pelaku dengan adanya kesadaran mengenai kemungkinan terjadinya suatu tindakan dan akibat yang terlarang yang mungkin akan terjadi apa bila perbuatan dilakukan

c. Sengaja sebagai kepastian adalah suatu tindakan atau perbuatan dari pelaku yang telah dapat diketahui atau dipastikan oleh pelaku bahwa perbuatan itu mempunyai kepastian akan menimbulkan akibat tertentu.

Maka dalam hal ini yang dimaksud dengan melawan hukum adalah "melawan hukum secara formil" yaitu "perbuatan yang melanggar / bertentangan dengan peraturan perundang-undangan / hukum tertulis". Istilah melawan hukum menggambarkan suatu pengertian tentang sifat tercelanya atau sifat terlarangnya suatu perbuatan.

Berdasarkan keterangan para Saksi yang saling bersesuaian antara satu dengan lainnya serta diperkuat dengan keterangan Terdakwa di depan persidangan maka diperoleh petunjuk bahwa pada kurun waktu bulan Januari sampai dengan Mei tahun 2018, bertempat di Kantor Depo PT. Anugerah Bina Usaha Nusantara (PT.ABUN) yang beralamat di Unit 2 Kabupaten Tulang Bawang Terdakwa bersama dengan Saksi Yohanes Adi Saputra Anak Dari sukoadi yang merupakan karyawan PT. Anugerah Bina Usaha Nusantara (PT.ABUN) yang menjabat selaku kepala depo dan kepala gudang melakukan penggelapan barangbarang milik PT. Anugerah Bina Usaha Nusantara (PT.ABUN).

Terdakwa pada bulan Maret Saksi Dian yang menjabat selaku Administrasi diperintahkan oleh Terdakwa dan saksi Yohanes untuk mencetak 9 (Sembilan) faktur penjualan serta Faktur batal sebanyak 2 (dua) faktur yang isinya fiktif dan Akibat Perbuatan Terdakwa bersamasama dengan Saksi Yohanes mengakibatkan Pihak PT.ABUN mengalami kerugian materiil sebesar Rp.84.342.600,- (delapan puluh empat juta tiga ratus empat puluh dua ribu dua ratus 
rupiah) dan perbuatan Terdakwa tersebut tanpa seizin pihak PT.ABUN.

Maka dengan ini penulis menyimpulkan bahwa unsur Dengan sengaja dan melawan hukum telah terpenuhi karena terdakwa secara sadar dan bersama sama dalam kurun waktu Januari sampai Maret telah memalsukan faktur penjualan dan faktur batal dengan niat untuk mengelabui PT. ABUN (Anugerah Bina Usaha Nusantara) agar barang tersebut bisa diambil olehnya sendiri. Unsur melawan hukum pun sudah terpenuhi dengan Terdakwa Solihin Bin Suwito melakukan penggelapan secara bersama sama yang mana diatur dalam pasal 374 KUHP dan pasal 55 KUHP.

3. Melakukan penggelapan yang penguasaannya terhadap barang disebabkan karena ada hubungan kerja atau karena pencarian atau karena mendapatkan upah untuk itu :

a. Terdakwa Solihin Bin Suwito melakukan penggelapan dengan cara membuat faktur fiktif dan akibat Perbuatan Terdakwa bersama-sama dengan Saksi Yohanes mengakibatkan Pihak PT.ABUN mengalami kerugian materiil sebesar Rp.84.342.600,(delapan puluh empat juta tiga ratus empat puluh dua ribu dua ratus rupiah). Perbuatan Terdakwa tersebut tanpa seizin pihak PT.ABUN.

b. Unsur Melakukan penggelapan yang penguasaannya terhadap barang disebabkan karena ada hubungan kerja atau karena pencarian atau karena mendapatkan upah untuk itu telah terpenuhi menurut hukum dibuktikan dengan Surat Keputusan No. : 018/SK/08/2014 Tentang Pengangkatan karyawan tetap atas nama Solihin sebagai kepala Depo tertanggal 04 Agustus 2014 dan Surat Keputusan No. : 025/SK/01/2015 Tentang pengangkatan karyawan tetap atas nama Yohanes Adi Saputra sebagai karyawan tetap sebagai kepala gudang tertanggal 02 Januari 2015 yang mana terdakwa secara sah merupakan karyawan PT. ABUN (Anugerah Bina Usaha Nusantara) dan menggunakan kewenangan sebagai kepala depo PT. ABUN untuk membuat faktur fiktif tersebut.

4. Mereka yang melakukan, yang menyuruh melakukan dan yang turut serta melakukan :

a. Unsur Mereka yang melakukan, yang menyuruh melakukan dan yang turut serta melakukan telah terpenuhi menurut hukum. Dengan melihat data yang ada dalam Berita Acara Pemeriksaan, keterangan Saksi, serta keterangan terdakwa yang selaras bahwa Solihin bin Suwito secara bersama sama dengan Yohanes Adi Putra membuat 9 faktur fiktif dan 2 faktur batal, bahwa dari alat bukti saksi dan bukti surat diatas dapat disimpulkan perbuatan Terdakwa terbukti dalam hal melakukna tindak pidana Penggelapan sehingga dengan demikian seluruh unsur yang terdapat dalam Pasal 374 KUHP Jo Pasal 55 ayat (1) KUHP telah terpenuhi menurut hukum;

Menurut hasil wawancara dengan Bapak Donny selaku Hakim Pengadilan Negeri Menggala menerangkan bahwa terdakwa dipersidangan menghadiri sendiri proses persidangan tanpa disampingi oleh penasehat hukum, yang telah didaftarkan di kepaniteraan Pengadilan Negeri Menggala putusan Nomor 71/Pid.B/2019/PN.Mgl tertanggal 26 Januari 2019.

Menurut hasil wawancara dengan Bapak Donny selaku Hakim Pengadilan Negeri Menggala menerangkan bahwa oleh karena dakwaan penuntut umum disusun secara dakwaan tunggal, maka Majelis Hakim dapat langsung mempertimbangkan dakwaan berdasarkan fakta-fakta dan bukti-bukti dipersidangan dan terdakwa didakwa melanggar Pasal 374 KUHP Jo Pasal 55 ayat (1) KUHP. 
Karena semua unsur dari Pasal 374 KUHP Jo Pasal 55 ayat (1) KUHP telah terpenuhi, maka Terdakwa haruslah dinyatakan telah terbukti secara sah dan meyakinkan melakukan tindak pidana sebagaimana didakwakan dalam dakwaan Tunggal;

Dalam persidangan, Majelis Hakim tidak menemukan hal-hal yang dapat menghapuskan pertanggungjawaban pidana, baik sebagai alasan pembenar dan atau alasan pemaaf, maka Terdakwa harus mempertanggungjawabkan perbuatannya. Oleh karena Terdakwa mampu bertanggung jawab, maka harus dinyatakan bersalah dan dijatuhi pidana;

Dalam perkara ini terhadap Terdakwa telah dikenakan penangkapan dan penahanan yang sah, maka masa penangkapan dan penahanan tersebut harus dikurangkan seluruhnya dari pidana yang dijatuhkan;

Terdakwa ditahan dan penahanan terhadap Terdakwa dilandasi alasan yang cukup, maka perlu ditetapkan agar Terdakwa tetap berada dalam tahanan. Lalu dengan adanya barang bukti yang diajukan di persidangan untuk selanjutnya dipertimbangkan

Upaya hukum hakim yang diputuskan oleh hakim adalah menjatuhkan hukuman bagi terdakwa yaitu 2 (dua) tahun dan oleh karena terdakwa tidak ada alasan hukum untuk mengeluarkan terdakwa tetap berada dalam tahanan.

Berdasarkan uraian diatas dapat diketahui bahwa upaya yang dilakukan oleh pemerintah untuk memberikan efek jera kepada pelaku tindak pidana percobaan melakukan pencurian dalam keadaan memberatkan, supaya tidak mengulangi lagi perbuatannya yaitu Jaksa Penuntut Umum memberikan dakwaan yang disusun secara dakwaan tunggal yang memenuhi Pasal 374 KUHP Jo Pasal 55 ayat (1) KUHP dan Undang-undang Nomor 8 Tahun 1981 tentang Hukum Acara Pidana.
Menurut hasil wawancara dengan Bapak Donny selaku Hakim Pengadilan Negeri Menggala menerangkan bahwa akan tetapi hakim dalam pertimbangannya telah mepertimbangkan terdakwa sesuai dengan apa yang memberatkan maupun hal-hal yang meringankan:

Keadaan yang memberatkan:

- Akibat perbuatan Terdakwa Pihak PT.ABUN mengalami kerugian materiil sebesar Rp.84.342.600,- (delapan puluh empat juta tiga ratus empat puluh dua ribu dua ratus rupiah);

Keadaan yang meringankan:

- Terdakwa belum pernah dihukum;

- Terdakwa mengakui dan menyesali perbuatannya;

-Terdakwa bersikap sopan dipersidangan;

Lebih lanjut dengan Bapak Donny menjelaskan bahwa dari keadaan yang memberatkan maupun yang meringankan bagi terdakwa tersebut diatas, maka pidana yang dijatuhkan sebagaimana disebutkan dalam putusan dirasakan telah sesuai dengan kesalahan terdakwa yang telah mendekati rasa keadilan dalam masyarakat dan terhadap masa penagkapan dan penahanan yang telah dijalani oleh terdakwa sesuai dengan ketentuan Pasal 374 KUHP Jo Pasal 55 ayat (1) KUHP. Dalam putusan Putusan Nomor 71/Pid.B/2019/PN.Mgl Majelis Hakim yang menjatuhkan Pidana kepada terdakwa Solihin Bin Suwito dengan pidana selama 2 (dua) tahun dan Terdakwa berada dalam tahanan dengan perintah agar terdakwa tetap ditahan.

Menurut pendapat penulis hukuman yang diberikan sudah berkesesuaian karena pidana yang dijatuhkan kepada terdakwa waktunya lebih lama dari pada masa penahanannya dan perbuatan terdakwa diyakini sebagai tindak pidana.

Menurut hasil wawancara dengan Bapak Donny selaku Hakim Pengadilan Negeri Menggala menerangkan bahwa pertimbangan hakim dalam menjatuhkan hukuman pada putusan Nomor 71/Pid.B/2019/PN.Mgl, berdasarkan 
beberapa pertimbangan. Terlebih dahulu hakim membaca dakwaan sesuai yang didakwakan penuntut umum. Setelah hakim membaca isi surat dakwaan tersebut, hakim lalu memastikan terbukti tidaknya terdakwa melakukan tindak pidana berdasarkan alat bukti dan pertimbangan yuridis.dengan memperhatikan Pasal 374 KUHP Jo Pasal 55 ayat (1) KUHP dan Undang-undang Nomor 8 Tahun 1981 tentang Hukum Acara Pidana serta peraturan perundangundangan lain yang bersangkutan dan hakim memutuskan:

1. Menyatakan Terdakwa Solihin Bin Suwito terbukti secara sah dan meyakinkan bersalah melakukan tindak pidana "yang melakukan Penggelapan dalam jabatan"

2. Menjatuhkan pidana kepada Terdakwa Solihin Bin Suwito oleh karena itu dengan pidana penjara selama 2 (dua) Tahun dengan ketentuan selama Terdakwa dalam masa tahanan dikurangkan seluruhnya dari pidana yang dijatuhkan kepadanya dengan perintah Terdakwa tetap dalam tahanan.

3. Memerintahkan Terdakwa tetap berada dalam tahanan;

4. Menetapkan barang bukti seperti yang terlampir diatas

5. Membebankan kepada Terdakwa untuk membayar biaya perkara sebesar Rp. 5.000 (lima ribu rupiah).

\section{PENUTUP}

\section{A. Kesimpulan}

Berdasarkan hasil penelitian dari pembahasan, maka penulis menyimpulkan beberapa hal diantaranya adalah sebagai berikut:

1. Penerapan hukum pidana materiil oleh Majelis Hakim terhadap pelaku tindak pidana penggelapan dalam jabatan yang menyatakan terdakwa secara sah dan meyakinkan bersalah melakukan tindak pidana penggelapan dalam jabatan sebagaimana diatur dalam pasal
374 KUHP Jo Pasal 55 ayat (1) ke-1 sudah tepat. Hal itu sesuai dengan fakta-fakta yang ada dalam persidangan, alat bukti dan keterangan para saksi. Serta terdakwa dianggap sehat secara jasmani dan rohani sehingga mampu mempertanggungjawabkan perbuatannya. Penerapan sanksi tersebut pun sudah sesuai dengan Rule of the law dari wewenang setiap lembaga dan peraturan yang mengaturnya.

2. Pertimbangan Hukum oleh Majelis Hakim dalam menjatuhkan hukuman dalam Putusan Nomor 71/Pid.B/2019/PN.Mgl di nilai sudah tepat. Karena berdasarkan fakta-fakta yang terungkap di persidangan, serta keterangan saksi maupun keterangan terdakwa, menurut penulis perbuatan terdakwa telah memenuhi unsur-unsur tindak pidana melakukan penggelapan dalam jabatan dengan pemberatan sebagai delik selesai, sebagaimana yang diatur dalam Pasal 374 KUHP Jo Pasal 55 ayat (1) KUHP dan terdakwa memenuhi syarat sebagai subjek hukum

\section{B. Saran}

Berdasarkan kesimpulan diatas makan penulis memberikan beberapa saran, yaitu:

1. Penerapan sanksi terhadap seseorang yang telah melakukan kejahatan sebisa mungkin diberikan hukuman yang setimpal dengan perbuatannya, agar memberikan efek jera dan tidak melakukan kembali kesalahannya dikemudian hari. Sanksi yang diberikan kepada setiap orang yang telah melakukan kejahatan harus disesuaikan dengan perbuatan yang dilakukan, fakta fakta yang terjadi dilapangan berdasarkan alat bukti yang ada, dan keterangan saksi saksi dalam sebuah persidangan.

Sudah seharusnya seseorang yang melakukan penggelapan dengan penggunaan jabatan diberikan sanksi 
yang tegas sehingga dapat menjadi pranata sosial bagi masyarakat sekitar.

2. Hakim memiliki tanggung jawab yang besar dalam menjatuhkan putusan. Jadi seorang hakim dalam memutuskan perkara harus seadil berdasarkan informasi atau fakta-fakta yang ada dalam persidangan agar masing-masing dari pihak tidak merasakan ketidakadilan yang akhirnya akan menyebabkan ketidakpercayaan masyarakat kepada penegak hukum dinegara kita.

Keputusan yang diambil oleh seorang hakim harus menjadi solusi dari permasalahan sosial yang di bawa ke dalam persidangan oleh masyarakat demi terciptanya kesejahteraan dan ketertiban dalam bermasyarakat.

\section{DAFTAR PUSTAKA}

Adami Chazawi. 2008. Pelajaran Hukum Pidana Bagian 2. PT Raja Grafindo, Jakarta.

Ahmad Abu Abdul Halim. 1996. Suap, Dampak dan Bahayanya. Pustaka alKautsar, Jakarta.

P.F. Lamintang. 1996. Dasar-Dasar Hukum Pidana Indonesia. PT. Citra Aditya Bakti, Bandung.

Ronny Hanityo Soemitro. 1980. Metodologi Penelitian Hukum Dan Jurimetri. Ghalia Indonesia, Jakarta.

Suharto RM. 1996. Hukum-Hukum Pidana Materiil Unsur-Unsur Obyektif Sebagai dasar Dakwaan Edisi Kedua, Sinar Grafika. Jakarta.

Teguh Prasetyo. 2011. Kriminalisasi dalam Hukum Pidana. Penerbit Nusa Media, Bandung.

Waluyadi. 2003. Hukum Pidana Indonesia. Djambatan, Jakarta.

\section{Perundang-Undangan}

Kitab Undang-Undang Hukum Pidana (KUHP)

Undang-UndangNomor 48 Tahun 2009 Tentang Kekuasaan Kehakiman

Undang-Undang Republik Indonesia Nomor 2 Tahun 2002 Tentang Kepolisian Negara Republik Indonesia

Peraturan Pemerintah Republik Indinesia Nomor 92 Tahun 2015 tentang perubahan kedua atas Peraturan Pemerintah Nomor 27 Tahun 1983 tentang pelaksanaan Kitab UndangUndang Hukum Acara Pidana (KUHAP)

\section{Sumber Lain}

Dekdikbud. 1999. Kamus BesarBahasa Indonesia. Balai Pustaka. Jakarta

Ahadian Ramadhan. 2014. Upaya Penanggulangan Tindak Pidana Penggelapan Kendaraan Bermotor Roda Empat Milik Rental (Studi Di Kepolisian Resor Malang Kota). Jurnal Hukum Fakultas Hukum Universitas Brawijaya.

Intan Nurina Seftiniara. 2015. Analisis Pertanggungjawaban Pidana Terhadap Pelaku Penipuan Perempuan Yang Dijadikan Pekerja Seks Komersial. Jurnal Ilmu Hukum Pranata Hukum Program Studi Magister Ilmu Hukum Program Pascasarjana, Universitas Bandar Lampung Volume 10 Nomor 2. 